Board of Governors of the Federal Reserve System

International Finance Discussion Papers

Number 1108

June 2014

\title{
The Energy Boom and Manufacturing in the United States
}

William R. Melick

Kenyon College

NOTE: International Finance Discussion Papers are preliminary materials circulated to stimulate discussion and critical comment. References in publications to International Finance Discussion Papers (other than an acknowledgment that the writer has had access to unpublished material) should be cleared with the author or authors. Recent IFDPs are available on the Web at www.federalreserve.gov/pubs/ifdp/. This paper can be downloaded without charge from Social Science Research Network electronic library at http://www.ssrn.com/. 


\title{
The Energy Boom and Manufacturing in the United States*
}

\author{
William R. Melick ${ }^{+}$
}

June 1, 2014

\begin{abstract}
This paper examines the response of U.S. manufacturers to changes in competitiveness brought about by movements in the price of natural gas. I estimate the response of various measures of manufacturing activity using panel regression methods across roughly 80 industries that allow each industry's response to vary with its energy intensity. These estimates suggest that the fall in the price of natural gas since 2006 is associated with a 2 to 3 percent increase in activity for the entire manufacturing sector, with much larger effects of 30 percent or more for the most energy intensive industries.
\end{abstract}

JEL Classification: D24, Q43

Keywords: Manufacturing, natural gas

\footnotetext{
* This work was completed while on a one-year assignment in the International Finance Division at the Federal Reserve Board. The paper has benefitted from conversations with Alessandro Barbarino, Kimberly Bayard, Charles Gilbert, Joseph Gruber, Paul Lengermann, Norman Morin, and participants in the International Finance Division Policy Workshop. Andrew Loucky, Keith Munz, and Mallorie Smith provided valuable research assistance. In addition, I am very grateful to Robert Adler, Tom Lorenz, and Derrick Pinckney of the Energy Information Administration for their help with the MECS data. None of these individuals are responsible for any remaining errors.
}

+Kenyon College, Gambier OH 43022, melickw@kenyon.edu. 


\section{Introduction}

Over the past eight years, the use of hydraulic fracturing techniques has significantly increased U.S. natural gas production (see Figure 1, top panel). This production increase has pushed U.S. natural gas prices down and has also provided a competitive advantage to those U.S. manufacturers that are intensive users of energy (Figure 1, bottom panel). This paper uses industry-level data on capital expenditure, production, employment, producer prices, imports, and exports to offer a preliminary empirical assessment of the impact of the drop in natural gas prices on U.S. manufacturing through this competitiveness channel.

In standard microeconomic theory, a positive supply shock for an important input such as energy will lead manufacturers to increase output, in turn pushing out the industry supply curve and lowering prices. To the extent that energy and labor are complementary inputs, manufacturing employment would also increase. If the positive energy supply shock were localized due to impediments to the trading of energy, which is the case for natural gas, exports of manufactured products should also increase while imports of these same products should fall. Moreover, investment in the manufacturing sector should increase as existing firms expand and reorient their production processes and new firms enter the sector. All of these effects should vary with the energy-intensity of the industry - the focus of this paper.

Overall, our estimates suggest that the roughly two-thirds decline in the price of natural gas in the United States relative to the price of natural gas in Europe has boosted activity in the manufacturing sector as a whole by perhaps two to three percent. Although a few industries are expanding, as of yet there does not appear to be a large effect across the entire manufacturing sector. For the handful of industries that are heavy users of natural gas, the estimated effects are much larger, on the order of a 30 percent or larger increase in activity. However, given that firms typically adjust their production processes only gradually, it may be that the full effect of the energy boom is still some years away. 


\section{Existing Literature}

The boom in the production of both oil and natural gas in the United States has generated a tremendous amount of commentary and analysis. Aside from largely descriptive work, such as PwC (2011) and Roberts (2013), only a handful of studies attempt to quantify the economic impact of the boom. In reviewing the results of these studies it is useful to draw a distinction between direct effects, indirect effects, and downstream or competitiveness effects. Direct effects capture changes in economic activity brought about by the increase in oil and gas extraction, for example the increased employment of oil field workers and petroleum engineers. Indirect effects capture the changes in economic activity for industries providing materials used in oil and gas extraction, for example the increased output of steel mills to produce the casing used on drilling rigs. Finally, downstream effects, the focus of this paper, are the changes in economic activity for industries that enjoy a lower price for energy inputs.

Houser and Mohan (2014), as part of a comprehensive study, provide some calculations to reach a qualitative conclusion regarding the size of the downstream effect. They calculate the change in production cost across U.S. manufacturing industries as a result of a drop in oil and natural gas prices. Based on these costs, they argue that relatively few industries, for example petrochemicals, will enjoy a substantial competitive advantage. They also warn that the competitive advantage could be fleeting if other countries can exploit their shale resources, if the United States begins to export substantial quantities of energy, or if the dollar appreciates in real terms as a result of the boom.

The analysis in IMF (2013) makes use of a six-region general equilibrium model to provide a quantitative assessment of the total economic impact of the oil and gas energy boom, characterizing the impact as "positive, but modest”. In the analysis, U.S. GDP increases less than 0.5 percent over the coming decade.

Morse et al (2012) provides an early estimate of the size of the downstream effect. They also use a computable general equilibrium model to calculate the impact of the energy boom in both oil and gas production. With regard to the downstream effect, labeled in their study as "gas-related multiplier effects” they find that by 2020 employment in manufacturing should increase by 1.1 million, a 9 percent 
increase relative to baseline. Their calculated downstream effect boosts real GDP by 0.2 percent above baseline by 2020, which seems modest by comparison as it implies a 1.6 percent increase in manufacturing output given that the manufacturing sector accounted for 12.5 percent of GDP in 2012.

Celasun et al (2014) only consider natural gas, using cross-country panel regressions to estimate the response of industrial production for the manufacturing sector as a whole in each country to changes in relative (domestic vs. world average) natural gas prices. They find that a doubling of the natural gas price differential in favor of the home country would increase manufacturing industrial production by 1.5 percent.

Finally, Sendich (2014) uses Granger causality tests to assess the relationship between natural gas prices and production for 12 energy-intensive manufacturing industries in the United States. She finds that for 8 of the 12 industries there does appear to be a significant relationship between natural gas prices and production, suggesting the possible importance of the downstream effect.

In short, the relatively few quantitative studies generally find positive but relatively small downstream effects, with the exception of the employment effects in Morse et al (2012).

\section{Data}

An empirical study that takes advantage of variation across industries in energy intensity obviously requires a variable that measures energy intensity. There are at least four measures of energy use that allow for the calculation of energy intensity by manufacturing industry. Foremost among these is the quadrennial Manufacturing Energy Consumption Survey (MECS) conducted by the Energy Information Administration within the Department of Energy. The latest MECS was conducted in 2010, with preliminary results released in March 2012 and complete results released by year-end 2013. Based on a survey of roughly 15,500 establishments, the MECS provides energy consumption by fuel for a collection of manufacturing industries representing a subset of the 3 to 6 digit North American Industry Classification System (NAICS). The MECS measures energy consumed as a fuel (e.g. heating and lighting) as well as energy consumed as a feedstock (e.g. naphtha used in the production of ethylene). Based on only fuel consumption, MECS provides several measures of energy intensity, notably total fuel 
consumption in thousands of British thermal units (Btu) per dollar of value added and total fuel consumption in thousands of British thermal units (Btu) per dollar of shipments. Note that both of these intensity measures exclude energy used as feedstock.

Given that a firm will benefit from a drop in energy prices whether it uses the energy as a fuel or as a feedstock, we calculate analogous measures of energy intensity for both total energy consumption and natural gas consumption in two steps. First, measures of value added and shipments for each industry covered by the MECS are constructed by dividing the MECS variable measuring Btu of total fuel consumption by the MECS variables measuring Btu of total fuel consumption per dollar of value added and Btu of total fuel consumption per dollar of shipments. ${ }^{1}$ Second, the MECS variables measuring Btu of total, both fuel and feedstock, energy consumption and total natural gas consumption are divided by the derived measure of industry value added or shipments to create variables that measure thousands of Btu of total energy and natural gas usage per dollar of value added and per dollar of shipments. All four of the resulting energy intensity variables are shown in Tables 1a (per dollar of value added) and 1b (per dollar of shipments).

Another measure of energy intensity can be derived from the Census Bureau’s Annual Survey of Manufactures (ASM). The ASM includes several questions on the purchase of energy, although purchases for fuels other than electricity are only available in dollar values. The ASM also provides measures of value added and shipments, allowing for a calculation of dollars of energy expenditure per dollar of value added and per dollar of shipments to produce energy intensity variables similar to the energy intensity variables derived from the MECS.

Within its annual industry accounts, the Bureau of Economic Analysis (BEA) produces the KLEM (Capital, Labor, Energy, Materials) dataset that allows for the calculation of energy use relative to value added. The KLEM data use the ASM data as an input and are mostly available at only the 3-digit NAICS level with a few 4-digit industries also included.

\footnotetext{
${ }^{1}$ This derived measure of value added is superior to a measure of value added taken directly from the Annual Survey of Manufactures as that measure covers every plant in the ASM, a much larger sample than the plants in the MECS.
} 
Finally, BEA’s Input/Output data can be used to construct measures of energy intensity by industry. Detailed data is available at five year intervals, with data for 2007 released in December 2013. Using the Input/Output data would require a substantial effort to carefully track energy expenditures into manufacturing that is unlikely to offer a superior measure compared to the data on quantities of energy consumption provided by the MECS.

Price declines have been most pronounced for natural gas, indicative of the segmented global market for that fuel. Industries that are intensive users of natural gas should benefit from the drop in prices, but so might energy-intensive industries that can switch to natural gas from other energy sources. In the empirical work to follow, we will focus on the measures of thousands of BTUs of total energy consumption and natural gas consumption per dollar of value-added and per dollar of shipments derived from the 2006 MECS survey and shown in Tables 1a and 1b. 2006 is close to the beginning of the resurgence in U.S. natural gas production, so this measure should provide the best indication of which industries stand to benefit the most from the positive supply shock. Table 2 confirms that the four MECS energy intensity measures are fairly highly correlated with intensity measures calculated from the ASM and KLEM data.

The MECS intensity data are matched by NAICS code with the following industry-level activity variables: capital expenditure, production, prices, employment, and trade flows. Every industry in the MECS data does not have an exact match for each activity variable because each agency involved in producing these activity variables covers a different set of manufacturing industries and implements the NAICS in slightly different ways. Nonetheless, there are quite a few matches. Table 3 describes the source of the data for each of the activity variables along with information on the period and the number of industries that can be matched to those in the MECS data. To avoid seasonality issues, and to simplify the subsequent econometric specification of lags, data in a native monthly frequency are converted to annual frequency. Table 3 also lists, for each measure of industry activity, the control variables used in the estimating equation that is discussed below. It is worth noting that the capital expenditure data is taken from the ASM, which unfortunately is currently only available through 2011, while the 
employment data is from the Bureau of Labor Statistic’s Quarterly Census of Employment and Wages that only has annual data through 2012. ${ }^{2}$ The other activity variables are available through 2013.

\section{Empirics}

Figures 2 anticipates the econometric specification, plotting the log change in industrial production since 2006 for each industry against the log of thousands of Btu of natural gas consumption per dollar of value added as of 2006. To avoid an uninformative cloud of data points and text, only points for the five and six digit industries in the sample, roughly 45 points, are plotted. All else equal, for industrial production one would expect to see a generally positive relationship whereby output increases relatively more for the firms that use natural gas intensively. The positive slope in Figure 2 is not overwhelming. ${ }^{3}$

However, the absence of control variables in the scatter plots may be obscuring the impact of the drop in natural gas prices. Therefore, a regression strategy is used to determine if the energy boom is playing out as expected with respect to intensity of energy use. Equation (1) provides a starting point for the analysis, using industrial production (IP) as an example.

$$
\ln \left(I P_{i, t}\right)=\beta_{0}+\delta \cdot \ln \left(I P_{i, t-1}\right)+\ln \left(Z_{t}\right) \cdot \gamma+\beta_{1} \cdot\left[\ln \left(N G_{t}\right) \cdot E I_{i, 2006}\right]+\beta_{2} \cdot\left[\ln \left(N G_{t-1}\right) \cdot E I_{i, 2006}\right]+\varepsilon_{i, t}
$$

where $Z_{t}$ represents a vector of control variables as of year $t$ multiplied by coefficient vector $\gamma, N G_{t}$ represents the price of natural gas in the United States relative to the price of natural gas in Europe in year $t, E I_{i, 2006}$ represents energy intensity, as of 2006, for industry $i$, and $\varepsilon_{i, t}$ is an error term. The relative price of natural gas is calculated as $\frac{N G_{t}^{U . S .}}{N G_{t}^{\text {Eur }}} \cdot 100$ where $N G_{t}^{\text {U.S. }}$ is the average price of natural gas at the Henry Hub in the United States during year $t$ and $N G_{t}^{E u r}$ is the average price of natural at the eastern German border in year $t$. The two natural gas prices are plotted in the bottom panel of Figure 1. Control variables for each equation are listed in Table 3, with descriptive statistics for all the variables presented in Table 4. The presence of the lagged dependent variable allows for industrial production to gradually

\footnotetext{
${ }^{2}$ By the end of 2014, data on capital expenditure should be available through 2013 following the release of the 2012 Economic Census.

${ }^{3}$ The nitrogenous fertilizers industry (NAICS code 325311) is noticeable in Figure 2 due to its outsize use of methane from natural gas to produce ammonia which is then used to produce nitric acid.
} 
change in response to a change in the relative price of natural gas, with the long-run effect calculated as $\frac{\beta_{1}+\beta_{2}}{1-\delta} \cdot E_{i, 2006}$.

In order to avoid estimation and inference problems with potentially non-stationary variables, consider the subtraction of a once-lagged version of equation (1) from itself to form the equation that is actually estimated.

(2) $\Delta \ln \left(I P_{i, t}\right)=\delta \cdot \Delta \ln \left(I P_{i, t-1}\right)+\Delta \ln \left(Z_{t}\right) \cdot \gamma+\beta_{1} \cdot\left[\Delta \ln \left(N G_{t}\right) \cdot E I_{i, 2006}\right]+\beta_{2} \cdot\left[\Delta \ln \left(N G_{t-1}\right) \cdot E I_{i, 2006}\right]+\varepsilon_{i, t}-\varepsilon_{i, t-1}$ Although the differencing in theory would eliminate any industry fixed effects, equation (2) is still estimated using fixed-effects in the event that equation (1) is mis-specified. Given estimates of the parameters from equation (2), the long-run multiplier is calculated as shown above. The log-log specification means that this long-run effect is interpreted as an elasticity. The estimated long-run elasticities should be negative and significant in the output, employment, export and capital expenditure equations as a drop in relative natural gas prices would lead firms to produce more, hire more, export more and invest more. Conversely, the long-run elasticity should be positive and significant in the price and import equations as a drop in natural gas prices would lead U.S. firms to lower prices and discourage imports from foreign manufactures.

Example estimation results for equation (2) using industrial production as the activity variable and thousands of Btu of natural gas consumption per dollar of value added as the energy intensity variable are presented in Table 5. From the results in the table, the long-run elasticity is calculated as

$$
\frac{\widehat{\beta}_{1}+\widehat{\beta}_{2}}{1-\widehat{\delta}} \cdot E_{i, 2006}=\frac{(-.0003484)+(-.0016216)}{1-(-.0775519)} \cdot E I_{i, 2006}=-0.00182822 \cdot E I_{i, 2006}
$$

The long-run elasticity ranges in value from -0.000137 for the least energy-intensive industry (Tobacco NAIC 3122, $E I_{2006}=0.075$ ) to -0.548641 for the most energy-intensive industry (Nitrogenous Fertilizers NAIC 325311, $\left.E I_{2006}=300.096\right)$ in the sample. The results in Table 5 are fairly typical of the estimates for all the activity measures across the four MECS-based energy intensity measures. ${ }^{4}$ In most cases, the signs on $\hat{\beta}_{1}$ and $\hat{\beta}_{2}$, the relative natural gas price energy intensity interaction coefficients,

\footnotetext{
${ }^{4}$ These estimates are not all tabled in order to save space. Full results are available from the author upon request.
} 
are as expected and are statistically significant at standard levels. Estimated coefficients on the lagged dependent variable, $\hat{\delta}$, tend to be negative, significant, and relatively small. The between and within values for $R^{2}$ are usually around 0.25 , with the overall $R^{2}$ near 0.20 .

With estimates like those in Table 5 it is possible to use the long-run elasticity to calculate the impact of a given change in the relative price of natural gas. From 2006 to 2013, the relative price of natural gas has fallen by about two-thirds, from a value of roughly 125 to a value of 40 . Given such a large change, the exact percentage change in the activity variable, for example $I P$, is calculated as

$$
\% \Delta I P_{i}=100 \cdot\left[\exp \left(\left(\frac{\hat{\beta}_{1}+\hat{\beta}_{2}}{1-\hat{\delta}}\right) \cdot \ln \left(\frac{40}{125}\right) \cdot E I_{i, 2006}\right)-1\right]
$$

As the subscripts in equation (4) make clear, these estimated responses will vary by industry.

Table 6a presents the estimated responses across the six measures of activity (capital expenditure, industrial production, employment, producer prices, import, and exports) and the four measures of energy intensity (natural gas consumption per dollar of value added and per dollar of shipments and total energy consumption per dollar of value added and per dollar of shipments). Table 6a is constructed by estimating equation (2) 24 times, once for each activity/intensity pair, giving 24 estimates of the long-run multiplier $\frac{\widehat{\beta}_{1}+\widehat{\beta}_{2}}{1-\widehat{\delta}}$. The response to the drop in the relative price of natural gas is then calculated for each of the 24 pairs using equation (4) for the least energy-intensive industry and the most energy-intensive industry. Note that in all of the 24 cases, the same drop in the relative natural gas price is used in equation (4) - a drop from an index value of 125 to an index value of 40. Table 6a also presents the probability value for a Wald test that the long-run elasticity is equal to zero. Finally, a weighted-average response across all the industries is calculated, with the weight based on each industry's share of total value added or total shipments depending on the measure of energy intensity. ${ }^{5}$

Several results stand out from Table 6a. First, and as expected, capital expenditure, industrial production, and employment have increased with the drop in the relative price of natural gas, and these

\footnotetext{
${ }^{5}$ Total is defined as the sum of value added or the sum of shipments across all the industries in the regression sample.
} 
increases are statistically significant. In terms of economic significance, the responses are quite large for the most energy-intensive industry. For example, the drop in the relative price of natural gas is associated with at least a five-fold increase in capital expenditure, at least a 50 percent increase in production, and a 30 percent increase in employment for the most energy-intensive industry. However, across the manufacturing sector as a whole, represented by the weighted average responses, the effects are quite modest, with capital expenditure increasing no more than 10 percent, production increasing less than 3 percent, and employment increasing less than 2 percent.

Second, results for imports, exports and prices are less clear-cut. As expected, imports fall in response to the drop in the relative price of natural gas, but the declines are usually not significant at standard levels. As with capital expenditures, production, and employment, the declines for the most energy-intensive industry are quite large, on the order of 30 percent but very modest for the manufacturing sector as a whole at less than 1 percent. For producer price and exports, the estimated responses are never statistically significant at standard levels, although they are of the expected sign. Effects across all industries are quite small. With regard to exports, it may be that firms are increasing the quantity of exports and also reducing the price charged for these exports, leaving the value of exports little changed.

All in all, the results in Table 6a build a convincing case that the most energy intensive industries respond to changes in the relative price of natural gas as would be expected. Similarly, across the entire manufacturing sector, responses to changes in the relative price of natural gas are much more modest, given that the sector as a whole has a much lower energy intensity. Reassuringly, these results appear to be quite robust to different ways of measuring energy intensity as there is not much variation in the calculated responses across the four measures of energy intensity.

However, given the outsized energy intensity for nitrogenous fertilizers, it is worth checking whether the results in Table 6a are mainly driven by this one industry. As can be seen in Table 6b, which repeats the estimates found in Table 6a for a sample that does not include nitrogenous fertilizers, it does not appear that the results are completely driven by one potential outlier. The responses for capital 
expenditure, industrial production and employment remain statistically significant and economically significant for the most energy-intensive industry. The response of capital expenditure for the most intensive industry is reduced quite a bit relative to Table 6a but still remains very large. Estimated responses for producer prices and imports remain statistically insignificant and in half of the cases are of the unexpected sign. However, the estimated response for exports excluding nitrogenous fertilizers is now statistically significant in one case, and much closer to conventional levels of significance in the other cases. All the estimated responses for exports continue to have the expected sign.

\section{Conclusion}

In summary, at this point in time these estimates suggest that the energy boom will have a relatively small impact for the manufacturing sector as a whole. The relative price of natural gas has fallen by two-thirds on balance over the past nine years. For the sector as a whole, this price drop is estimated to induce a roughly 10 percent increase in capital expenditure and perhaps a two to three percent change in production and employment - not trivial but by no means overwhelming. Results are quite a bit stronger for the most intensive users of energy. For these industries, the drop in the relative price of natural gas is associated with at least a tripling of capital expenditure, an almost 40 percent increase in production and a 30 percent increase in employment.

Moreover, these estimates seem broadly consistent with earlier work. Celasun et al (2014) finds that a halving of relative natural gas prices leads to a 1.5 percent increase in industrial production, while the results of Morse et al (2012) are consistent with a 1.6 percent increase in manufacturing output. The only anomaly appears to be the outsized employment gains reported by Morse et al. Their 9 percent increase in manufacturing employment is quite a bit larger than the roughly 2 percent increases found in this study (Tables 6a and 6b).

The findings in this paper point to two possible conclusions. On the one hand, it could be that the energy boom will only ever be noticeable for the most intensive users of natural gas in the manufacturing sector. These intensive users make up a fairly small piece of the sector so that the overall impact on the entire sector will be relatively modest. For example, the four most intensive users of natural gas based on 
thousands of Btu per dollar of value added (Table 1a) are: Nitrogenous Fertilizers, Alkalies and Chlorine, Carbon Black, and Flat Glass. In 2011, these four industries accounted for 0.5 percent of value added in manufacturing.

Alternatively, the timing of manufacturers' adjustment to more abundant natural gas will also surely vary by the intensity of natural gas usage. Early impacts should be seen in the most intensive industries, with others to follow. Moreover, these early impacts are likely to first register in capital expenditures for which data are only available through 2011. Perhaps the impact of the energy boom has yet to appear in the lagging data or yet to fully play out, calling for continued monitoring and analysis of developments in the manufacturing sector. 


\section{References}

Celasun, Oya, Gabriel Di Bella, Tim Mahedy and Chris Papageorgiou, (2014) “The U.S. Manufacturing Recovery: Uptick or Renaissance?” International Monetary Fund Working Paper WP/14/28

Houser, Trevor and Shashank Mohan, (2014) Fueling Up The Economic Implications of America's Oil and Gas Boom, Peterson Institute for International Economics, Washington DC.

International Monetary Fund, (2013) “United States 2013 Article IV Consultation - Selected Issues” IMF Country Report No. 13/237, July.

Morse, Edward L., Eric G. Lee, Daniel P. Ahn, Aakash Doshi, Seth M. Kleinman, and Anthony Yuen, (2012) “Energy 2020: North America the New Middle East?” Citi GPS: Global Perspectives and Solutions.

PwC (Price Waterhouse Coopers), (2011) Shale Gas: A Renaissance in U.S. Manufacturing?, December.

Roberts, Seth, (2013) "Building a Manufacturing Renaissance on the Shale Boom” Dow Chemical Company presentation at 2013 National Association of Business Economists Conference, May.

Sendich, Elizabeth (2014) "The Importance of Natural Gas in the Industrial Sector With a Focus on Energy-Intensive Industries,” U.S. Energy Information Administration, Working Paper Series. 
Table 1a

Energy Consumption by Industry in the 2006 Manufacturing Energy Consumption Survey

(Thousand BTUs per \$ of Value Added)

\begin{tabular}{|c|c|c|c|c|c|c|c|}
\hline $\begin{array}{l}\text { NAIC } \\
\text { Code }\end{array}$ & Industry & $\begin{array}{c}\text { Total } \\
\text { Energy }\end{array}$ & $\begin{array}{c}\text { Natural } \\
\text { Gas }\end{array}$ & $\begin{array}{l}\text { NAIC } \\
\text { Code }\end{array}$ & Industry & $\begin{array}{c}\text { Total } \\
\text { Energy }\end{array}$ & $\begin{array}{c}\text { Natural } \\
\text { Gas }\end{array}$ \\
\hline 311 & Food & 5.0 & 2.7 & 3254 & Pharmaceuticals and Medicines & 0.7 & 0.3 \\
\hline 3112 & Grain and Oilseed Milling & 17.6 & 6.6 & 325412 & Pharmaceutical Preparation & 0.6 & 0.3 \\
\hline 311221 & Wet Corn Milling & 43.6 & 12.7 & 325992 & Photographic Film, Paper, Plate, and Chemicals & 3.8 & 1.0 \\
\hline 31131 & Sugar Manufacturing & 31.3 & 6.9 & 326 & Plastics and Rubber Products & 3.7 & 1.4 \\
\hline 3114 & Fruit and Vegetable Preserving and Specialty Foods & 5.5 & 4.1 & 327 & Nonmetallic Mineral Products & 17.6 & 7.3 \\
\hline 3115 & Dairy Products & 4.3 & 2.9 & 327211 & Flat Glass & 39.0 & 29.4 \\
\hline 3116 & Animal Slaughtering and Processing & 4.4 & 2.8 & 327212 & Other Pressed and Blown Glass and Glassware & 40.8 & 0.0 \\
\hline 312 & Beverage and Tobacco Products & 1.4 & 0.5 & 327213 & Glass Containers & 24.3 & 19.0 \\
\hline 3121 & Beverages & 2.4 & 0.9 & 327215 & Glass Products from Purchased Glass & 9.8 & 7.8 \\
\hline 3122 & Tobacco & 0.3 & 0.1 & 32731 & Cements & 52.5 & 2.7 \\
\hline 313 & Textile Mills & 8.6 & 3.1 & 32741 & Lime & 120.1 & 5.2 \\
\hline 314 & Textile Product Mills & 4.6 & 2.9 & 32742 & Gypsum & 18.7 & 16.5 \\
\hline 315 & Apparel & 1.0 & 0.5 & 327993 & Mineral Wool & 12.7 & 8.7 \\
\hline 316 & Leather and Allied Products & 1.1 & 0.4 & 331 & Primary Metals & 19.9 & 7.2 \\
\hline 321 & Wood Products & 10.5 & 2.0 & 331111 & Iron and Steel Mills & 34.2 & 11.8 \\
\hline 321113 & Sawmills & 15.2 & 1.3 & 331112 & Electrometallurgical Ferroalloy Products & 46.7 & 2.1 \\
\hline 3212 & Veneer, Plywood, and Engineered Woods & 17.6 & 4.7 & 3312 & Steel Products from Purchased Steel & 6.5 & 3.0 \\
\hline 3219 & Other Wood Products & 5.7 & 1.2 & 3313 & Alumina and Aluminum & 25.5 & 10.4 \\
\hline 322 & Paper & 28.9 & 5.8 & 331314 & Secondary Smelting and Alloying of Aluminum & 16.1 & 13.8 \\
\hline 32211 & Pulp Mills & 113.2 & 7.4 & 331315 & Aluminum Sheet, Plate and Foils & 13.6 & 9.7 \\
\hline 322121 & Paper Mills, except Newsprint & 35.3 & 6.5 & 331316 & Aluminum Extruded Products & 8.6 & 5.8 \\
\hline 322122 & Newsprint Mills & 40.8 & 4.5 & 3314 & Nonferrous Metals, except Aluminum & 9.2 & 2.7 \\
\hline 32213 & Paperboard Mills & 64.4 & 11.1 & 3315 & Foundries & 8.3 & 3.7 \\
\hline 323 & Printing and Related Support & 1.5 & 0.7 & 331511 & Iron Foundries & 12.6 & 3.6 \\
\hline 324 & Petroleum and Coal Products & 54.6 & 6.8 & 331521 & Aluminum Die-Casting Foundries & 9.8 & 6.7 \\
\hline 32411 & Petroleum Refineries & 59.9 & 7.1 & 331524 & Aluminum Foundries, except Die-Casting & 8.4 & 6.5 \\
\hline 324199 & Other Petroleum and Coal Products & 158.5 & 3.4 & 332 & Fabricated Metal Products & 2.6 & 1.6 \\
\hline 325 & Chemicals & 15.2 & 5.2 & 333 & Machinery & 1.2 & 0.5 \\
\hline 32511 & Petrochemicals & 39.6 & 4.3 & 334 & Computer and Electronic Products & 0.7 & 0.2 \\
\hline 32512 & Industrial Gases & 33.8 & 15.4 & 334413 & Semiconductors and Related Devices & 1.2 & 0.4 \\
\hline 325181 & Alkalies and Chlorine & 61.9 & 43.3 & 335 & Electrical Equip., Appliances, and Components & 2.1 & 0.9 \\
\hline 325182 & Carbon Black & 141.7 & 31.7 & 336 & Transportation Equipment & 1.7 & 0.9 \\
\hline 325188 & Other Basic Inorganic Chemicals & 19.0 & 5.7 & 336111 & Automobiles & 1.5 & 0.8 \\
\hline 325192 & Cyclic Crudes and Intermediates & 8.8 & 3.8 & 336112 & Light Trucks and Utility Vehicles & 1.3 & 0.8 \\
\hline 325193 & Ethyl Alcohol & 24.6 & 17.9 & 3364 & Aerospace Product and Parts & 0.9 & 0.4 \\
\hline 325199 & Other Basic Organic Chemicals & 42.0 & 15.7 & 336411 & Aircraft & 0.6 & 0.2 \\
\hline 325211 & Plastics Materials and Resins & 68.9 & 15.3 & 337 & Furniture and Related Products & 1.1 & 0.3 \\
\hline 325212 & Synthetic Rubber & 17.8 & 10.5 & 339 & Miscellaneous & 0.6 & 0.2 \\
\hline 325222 & Noncellulosic Organic Fibers & 21.6 & 10.1 & & & & \\
\hline 325311 & Nitrogenous Fertilizers & 309.3 & 300.1 & & & & \\
\hline 325312 & Phosphatic Fertilizers & 21.7 & 15.3 & & & & \\
\hline
\end{tabular}


Table $1 b$

Energy Consumption by Industry in the 2006 Manufacturing Energy Consumption Survey

(Thousand BTUs per \$ of Shipments)

\begin{tabular}{|c|c|c|c|c|c|c|c|}
\hline $\begin{array}{l}\text { NAIC } \\
\text { Code }\end{array}$ & Industry & $\begin{array}{c}\text { Total } \\
\text { Energy }\end{array}$ & $\begin{array}{c}\text { Natural } \\
\text { Gas }\end{array}$ & $\begin{array}{l}\text { NAIC } \\
\text { Code }\end{array}$ & Industry & $\begin{array}{c}\text { Total } \\
\text { Energy }\end{array}$ & $\begin{array}{c}\text { Natural } \\
\text { Gas }\end{array}$ \\
\hline 311 & Food & 2.2 & 1.2 & 3254 & Pharmaceuticals and Medicines & 0.5 & 0.3 \\
\hline 3112 & Grain and Oilseed Milling & 5.7 & 2.2 & 325412 & Pharmaceutical Preparation & 0.5 & 0.2 \\
\hline 311221 & Wet Corn Milling & 18.2 & 5.3 & 325992 & Photographic Film, Paper, Plate, and Chemicals & 2.4 & 0.6 \\
\hline 31131 & Sugar Manufacturing & 12.2 & 2.7 & 326 & Plastics and Rubber Products & 1.7 & 0.6 \\
\hline 3114 & Fruit and Vegetable Preserving and Specialty Foods & 2.8 & 2.1 & 327 & Nonmetallic Mineral Products & 9.8 & 4.0 \\
\hline 3115 & Dairy Products & 1.3 & 0.9 & 327211 & Flat Glass & 21.2 & 15.9 \\
\hline 3116 & Animal Slaughtering and Processing & 1.6 & 1.0 & 327212 & Other Pressed and Blown Glass and Glassware & 24.9 & 0.0 \\
\hline 312 & Beverage and Tobacco Products & 0.9 & 0.3 & 327213 & Glass Containers & 14.1 & 11.0 \\
\hline 3121 & Beverages & 1.1 & 0.4 & 327215 & Glass Products from Purchased Glass & 5.1 & 4.1 \\
\hline 3122 & Tobacco & 0.3 & 0.1 & 32731 & Cements & 34.0 & 1.8 \\
\hline 313 & Textile Mills & 4.1 & 1.5 & 32741 & Lime & 75.8 & 3.3 \\
\hline 314 & Textile Product Mills & 1.8 & 1.2 & 32742 & Gypsum & 11.0 & 9.7 \\
\hline 315 & Apparel & 0.5 & 0.3 & 327993 & Mineral Wool & 8.0 & 5.5 \\
\hline 316 & Leather and Allied Products & 0.6 & 0.2 & 331 & Primary Metals & 7.5 & 2.7 \\
\hline 321 & Wood Products & 4.1 & 0.8 & 331111 & Iron and Steel Mills & 12.9 & 4.4 \\
\hline 321113 & Sawmills & 5.0 & 0.4 & 331112 & Electrometallurgical Ferroalloy Products & 22.6 & 1.0 \\
\hline 3212 & Veneer, Plywood, and Engineered Woods & 6.8 & 1.8 & 3312 & Steel Products from Purchased Steel & 2.5 & 1.1 \\
\hline 3219 & Other Wood Products & 2.5 & 0.5 & 3313 & Alumina and Aluminum & 7.0 & 2.8 \\
\hline 322 & Paper & 13.7 & 2.8 & 331314 & Secondary Smelting and Alloying of Aluminum & 2.7 & 2.3 \\
\hline 32211 & Pulp Mills & 49.9 & 3.2 & 331315 & Aluminum Sheet, Plate and Foils & 3.3 & 2.3 \\
\hline 322121 & Paper Mills, except Newsprint & 19.6 & 3.6 & 331316 & Aluminum Extruded Products & 2.5 & 1.7 \\
\hline 322122 & Newsprint Mills & 20.9 & 2.3 & 3314 & Nonferrous Metals, except Aluminum & 2.9 & 0.8 \\
\hline 32213 & Paperboard Mills & 32.3 & 5.5 & 3315 & Foundries & 4.7 & 2.1 \\
\hline 323 & Printing and Related Support & 1.0 & 0.5 & 331511 & Iron Foundries & 6.5 & 1.9 \\
\hline 324 & Petroleum and Coal Products & 12.3 & 1.5 & 331521 & Aluminum Die-Casting Foundries & 4.9 & 3.3 \\
\hline 32411 & Petroleum Refineries & 12.9 & 1.5 & 331524 & Aluminum Foundries, except Die-Casting & 4.3 & 3.4 \\
\hline 324199 & Other Petroleum and Coal Products & 52.7 & 1.1 & 332 & Fabricated Metal Products & 1.3 & 0.8 \\
\hline 325 & Chemicals & 8.2 & 2.8 & 333 & Machinery & 0.6 & 0.2 \\
\hline 32511 & Petrochemicals & 16.5 & 1.8 & 334 & Computer and Electronic Products & 0.4 & 0.1 \\
\hline 32512 & Industrial Gases & 18.6 & 8.5 & 334413 & Semiconductors and Related Devices & 0.9 & 0.3 \\
\hline 325181 & Alkalies and Chlorine & 32.0 & 22.4 & 335 & Electrical Equip., Appliances, and Components & 0.9 & 0.4 \\
\hline 325182 & Carbon Black & 57.2 & 12.8 & 336 & Transportation Equipment & 0.6 & 0.3 \\
\hline 325188 & Other Basic Inorganic Chemicals & 10.8 & 3.2 & 336111 & Automobiles & 0.4 & 0.2 \\
\hline 325192 & Cyclic Crudes and Intermediates & 5.1 & 2.2 & 336112 & Light Trucks and Utility Vehicles & 0.3 & 0.2 \\
\hline 325193 & Ethyl Alcohol & 14.1 & 10.3 & 3364 & Aerospace Product and Parts & 0.4 & 0.2 \\
\hline 325199 & Other Basic Organic Chemicals & 14.1 & 5.3 & 336411 & Aircraft & 0.2 & 0.1 \\
\hline 325211 & Plastics Materials and Resins & 21.0 & 4.7 & 337 & Furniture and Related Products & 0.6 & 0.2 \\
\hline 325212 & Synthetic Rubber & 6.0 & 3.5 & 339 & Miscellaneous & 0.4 & 0.2 \\
\hline 325222 & Noncellulosic Organic Fibers & 8.4 & 3.9 & & & & \\
\hline 325311 & Nitrogenous Fertilizers & 90.1 & 87.4 & & & & \\
\hline 325312 & Phosphatic Fertilizers & 5.3 & 3.7 & & & & \\
\hline
\end{tabular}


Table 2

Correlations Between Measures of Energy Intensity in Manufacturing

\begin{tabular}{|c|c|c|c|c|c|c|}
\hline & & observations) & & & & \\
\hline & $\begin{array}{c}\text { MECS } \\
\text { Total Energy } \\
\text { per \$ of } \\
\text { Value Added }\end{array}$ & $\begin{array}{c}\text { MECS } \\
\text { Natural Gas } \\
\text { per \$ of } \\
\text { Value Added }\end{array}$ & $\begin{array}{c}\text { MECS } \\
\text { Total Energy } \\
\text { per \$ of } \\
\text { Shipments }\end{array}$ & $\begin{array}{c}\text { MECS } \\
\text { Natural Gas } \\
\text { per \$ of } \\
\text { Shipments }\end{array}$ & $\begin{array}{c}\text { ASM } \\
\text { Fuel Use per } \\
\$ \text { of Value } \\
\text { Added }\end{array}$ & $\begin{array}{c}\text { ASM } \\
\text { Total Energy } \\
\text { per \$ of } \\
\text { Value Added }\end{array}$ \\
\hline MECS Natural Gas per \$ of Value Added & $\begin{array}{c}0.7716 \\
(78)\end{array}$ & & & & & \\
\hline MECS Total Energy per \$ of Shipments & $\begin{array}{c}0.9409 \\
(79)\end{array}$ & $\begin{array}{c}0.6129 \\
(78)\end{array}$ & & & & \\
\hline MECS Natural Gas per \$ of Shipments & $\begin{array}{c}0.7709 \\
(78)\end{array}$ & $\begin{array}{c}0.9853 \\
(78)\end{array}$ & $\begin{array}{c}0.6433 \\
(78)\end{array}$ & & & \\
\hline ASM Fuel Use per \$ of Value Added & $\begin{array}{c}0.3674 \\
(14)\end{array}$ & $\begin{array}{c}0.7936 \\
(14)\end{array}$ & $\begin{array}{c}0.6713 \\
(14)\end{array}$ & $\begin{array}{c}0.8707 \\
(14)\end{array}$ & & \\
\hline ASM Total Energy per \$ of Value Added & $\begin{array}{c}0.6843 \\
(65)\end{array}$ & $\begin{array}{c}0.5518 \\
(64)\end{array}$ & $\begin{array}{c}0.7657 \\
(65)\end{array}$ & $\begin{array}{c}0.6268 \\
(64)\end{array}$ & $\begin{array}{c}0.7592 \\
(14)\end{array}$ & \\
\hline KLEM Total Energy per \$ of Value Added & $\begin{array}{c}0.6835 \\
(62)\end{array}$ & $\begin{array}{c}0.5401 \\
(61)\end{array}$ & $\begin{array}{c}0.7651 \\
(62)\end{array}$ & $\begin{array}{c}0.595 \\
(61)\end{array}$ & $\begin{array}{c}0.8711 \\
(14)\end{array}$ & $\begin{array}{l}0.907 \\
(492)\end{array}$ \\
\hline
\end{tabular}


Table 3

Manufacturing Economic Activity Variables

Right Hand Side Control Variables

Number of Industries Number of Industries

Overlapping with

Overlapping with

MECS Natural Gas MECS Total Energy

Intensity Variables Intensity Variables

\begin{tabular}{|l|l|l|c|c|}
\hline Capital Expenditure (Census ASM) & $1997-2011$ & US GDP, Oil Price & 78 & 79 \\
\hline Industrial Production (FRB) & $1997-2013$ & US GDP, Oil Price & 78 \\
\hline Employment QCEW (BLS) & $1997-2012$ & US GDP, Oil Price & 79 \\
\hline Producer Price Index (BLS) & $1997-2013$ & US GDP, Commodity Prices, Oil Price & 78 \\
\hline Imports (USITC) & $1997-2013$ & US GDP, Real Exchange Rate, Commodity Prices, Oil Price & 79 \\
\hline Exports (USITC) & $1997-2013$ & Foreign GDP, Real Exchange Rate, Oil Price & 75 \\
\hline
\end{tabular}




\begin{tabular}{|c|c|c|c|c|c|c|}
\hline \multicolumn{7}{|c|}{ Table 4} \\
\hline \multicolumn{7}{|c|}{ Descriptive Statistics } \\
\hline Activity Variables & Units & Observations & Mean & $\begin{array}{l}\text { Standard } \\
\text { Deviation }\end{array}$ & Minimum & Maximum \\
\hline Capital Expenditure & Millions of $\$$ & 1245 & 2584.40 & 4196.6 & 15.34 & 28059.77 \\
\hline Industrial Production & Index, 2007=100 & 1411 & 95.49 & 26.3 & 2.09 & 441.80 \\
\hline Employment & Thousands & 1306 & 234.61 & 385.0 & 1.13 & 2088.65 \\
\hline Producer Price Index & Index, 1982=100 & 954 & 163.18 & 74.9 & 39.48 & 580.28 \\
\hline Imports & Billions of $\$$ & 1360 & 22522.29 & 46485.4 & 5.81 & 358174.80 \\
\hline Exports & Billions of $\$$ & 1360 & 17026.53 & 35673.2 & 6.86 & 255723.50 \\
\hline \multicolumn{7}{|l|}{ Energy Intensity Variables } \\
\hline Natural Gas in Value Added & Thousands of Btu per $\$$ & 266 & 12.49 & 44.3 & 0.08 & 478.10 \\
\hline Total Energy in Value Added & Thousands of Btu per $\$$ & 271 & 35.01 & 60.7 & 0.30 & 490.94 \\
\hline Natural Gas in Shipments & Thousands of Btu per $\$$ & 266 & 4.98 & 15.8 & 0.08 & 189.83 \\
\hline Total Energy in Shipments & Thousands of Btu per $\$$ & 271 & 14.10 & 22.2 & 0.20 & 196.47 \\
\hline \multicolumn{7}{|l|}{ Control Variables } \\
\hline Price of Oil (West Texas Intermediate) & $\$$ per barrel & 17 & 54.82 & 30.8 & 14.40 & 99.56 \\
\hline U.S. Price of Natural Gas (Henry Hub) & $\$$ per Million Btu & 17 & 4.71 & 2.1 & 2.09 & 8.85 \\
\hline European Price of Natural Gas (German Border) & \$ per Million Btu & 17 & 6.48 & 3.8 & 1.81 & 13.14 \\
\hline U.S. Real GDP & Billions of Chained $2009 \$$ & 17 & 13756.10 & 1422.3 & 11022.88 & 15761.31 \\
\hline Foreign Real GDP & Index, $2009=100$ & 17 & 92.32 & 13.4 & 72.39 & 113.91 \\
\hline Real Exchange Rate & Index, $2009=100$ & 17 & 104.61 & 9.6 & 90.38 & 120.67 \\
\hline Commodity Price Index & Index, $1995=100$ & 17 & 117.15 & 39.9 & 74.45 & 192.31 \\
\hline
\end{tabular}


Table 5

Example Fixed Effects Estimation Results

Activity Measure - Change in Log Industrial Production $\Delta \ln \left(I P_{i, t}\right)$

Energy Intensity Measure - Thousands of Btu of Natural Gas Consumption per $\$$ of Value Added

\begin{tabular}{|c|c|c|}
\hline Independent Variables & Coefficient & t-Statistic \\
\hline Lagged Change in Log Industrial Production $\Delta \ln \left(I P_{i, t-1}\right)$ & -0.07755 & -2.76 \\
\hline Change in Log GDP & 2.21222 & 9.61 \\
\hline Change in Log Oil Price & 0.37335 & 2.03 \\
\hline Lagged Change in Log Oil Price & -0.05604 & -4.60 \\
\hline $\begin{array}{l}\text { Change in Log Relative Price of Natural Gas Interacted with Energy Intensity } \\
\Delta \ln \left(N G_{t} \cdot E I_{i}\right)\end{array}$ & -0.00035 & -1.31 \\
\hline $\begin{array}{l}\text { Lag Change in Log Relative Price of Natural Gas Interacted with Energy } \\
\text { Intensity } \Delta \ln \left(N G_{t-1} \cdot E I_{i}\right)\end{array}$ & -0.00162 & -5.63 \\
\hline Number of Industries & \multicolumn{2}{|c|}{78} \\
\hline Years & \multicolumn{2}{|c|}{$15,1999-2013$} \\
\hline Number of Observations & \multicolumn{2}{|c|}{1170} \\
\hline $\begin{array}{r}\text { R-Squared } \\
\text { Within } \\
\text { Between } \\
\text { Overall }\end{array}$ & \multicolumn{2}{|c|}{$\begin{array}{l}0.2677 \\
0.3140 \\
0.1897 \\
\end{array}$} \\
\hline
\end{tabular}




\begin{tabular}{|c|c|c|c|c|}
\hline \multicolumn{5}{|c|}{$\begin{array}{c}\text { Table 6a } \\
\text { Long-Run Responses in Industry Activity to a Two-Thirds Decline in Relative Natural Gas Prices } \\
\text { (percent) }\end{array}$} \\
\hline & Minimum & Maximum & Wald Test & Weighted \\
\hline & Intenstity & Intensity & Response $=0$ & Average \\
\hline \multirow[t]{2}{*}{ Measure of Energy Intensity } & Industry & Industry & $p$-Value & Response* \\
\hline & \multicolumn{4}{|c|}{ Capital Expenditure } \\
\hline Natural Gas per $\$$ of Value Added & 0.05 & 779.54 & 0.00 & 3.45 \\
\hline Natural Gas per \$ of Shipments & 0.18 & 751.98 & 0.00 & 4.34 \\
\hline Total Energy per $\$$ of Value Added & 0.20 & 681.94 & 0.00 & 9.96 \\
\hline \multirow[t]{2}{*}{ Total Energy per $\$$ of Shipments } & 0.33 & 344.02 & 0.00 & 10.91 \\
\hline & \multicolumn{4}{|c|}{ Industrial Production } \\
\hline Natural Gas per $\$$ of Value Added & 0.02 & 86.85 & 0.00 & 0.77 \\
\hline Natural Gas per \$ of Shipments & 0.05 & 89.80 & 0.00 & 1.14 \\
\hline Total Energy per $\$$ of Value Added & 0.05 & 71.88 & 0.00 & 2.24 \\
\hline \multirow[t]{2}{*}{ Total Energy per \$ of Shipments } & 0.09 & 51.91 & 0.00 & 2.79 \\
\hline & \multicolumn{4}{|c|}{ Employment } \\
\hline Natural Gas per $\$$ of Value Added & 0.01 & 26.95 & 0.02 & 0.27 \\
\hline Natural Gas per \$ of Shipments & 0.02 & 30.36 & 0.01 & 0.44 \\
\hline Total Energy per $\$$ of Value Added & 0.03 & 43.42 & 0.00 & 1.42 \\
\hline \multirow[t]{2}{*}{ Total Energy per \$ of Shipments } & 0.06 & 32.89 & 0.00 & 1.83 \\
\hline & \multicolumn{4}{|c|}{ Producer Prices } \\
\hline Natural Gas per $\$$ of Value Added & 0.00 & -7.62 & 0.50 & -0.09 \\
\hline Natural Gas per \$ of Shipments & 0.00 & -4.67 & 0.68 & -0.08 \\
\hline Total Energy per $\$$ of Value Added & -0.01 & -13.90 & 0.12 & -0.58 \\
\hline \multirow[t]{2}{*}{ Total Energy per \$ of Shipments } & -0.02 & -7.01 & 0.39 & -0.48 \\
\hline & \multicolumn{4}{|c|}{ Imports } \\
\hline Natural Gas per $\$$ of Value Added & -0.01 & -34.96 & 0.08 & -0.49 \\
\hline Natural Gas per \$ of Shipments & -0.03 & -28.27 & 0.15 & -0.57 \\
\hline Total Energy per $\$$ of Value Added & -0.03 & -25.74 & 0.11 & -1.15 \\
\hline \multirow[t]{2}{*}{ Total Energy per \$ of Shipments } & -0.01 & -6.52 & 0.63 & -0.44 \\
\hline & \multicolumn{4}{|c|}{ Exports } \\
\hline Natural Gas per $\$$ of Value Added & 0.00 & 18.93 & 0.52 & 0.21 \\
\hline Natural Gas per \$ of Shipments & 0.02 & 28.85 & 0.32 & 0.45 \\
\hline Total Energy per $\$$ of Value Added & 0.02 & 19.17 & 0.40 & 0.70 \\
\hline Total Energy per \$ of Shipments & 0.04 & 20.37 & 0.24 & 1.23 \\
\hline
\end{tabular}

* Weighted by each industry's share of total value added or total shipments 


\begin{tabular}{|c|c|c|c|c|}
\hline \multicolumn{5}{|c|}{$\begin{array}{c}\text { Table 6b } \\
\text { Long-Run Responses in Industry Activity to a Two-Thirds Decline in Relative Natural Gas Prices } \\
\text { Excluding Nitrogenous Fertilizers (NAIC 325311) } \\
\text { (percent) }\end{array}$} \\
\hline & Minimum & Maximum & Wald Test & Weighted \\
\hline & Intenstity & Intensity & Response $=0$ & Average \\
\hline \multirow[t]{2}{*}{ Measure of Energy Intensity } & Industry & Industry & p-Value & Response* \\
\hline & \multicolumn{4}{|c|}{ Capital Expenditure } \\
\hline Natural Gas per $\$$ of Value Added & 0.17 & 171.62 & 0.00 & 7.71 \\
\hline Natural Gas per \$ of Shipments & 0.32 & 157.19 & 0.00 & 6.38 \\
\hline Total Energy per $\$$ of Value Added & 0.21 & 208.75 & 0.00 & 9.67 \\
\hline \multirow[t]{2}{*}{ Total Energy per \$ of Shipments } & 0.30 & 208.24 & 0.00 & 9.39 \\
\hline & \multicolumn{4}{|c|}{ Industrial Production } \\
\hline Natural Gas per $\$$ of Value Added & 0.05 & 36.83 & 0.00 & 2.27 \\
\hline Natural Gas per \$ of Shipments & 0.11 & 39.27 & 0.00 & 2.14 \\
\hline Total Energy per $\$$ of Value Added & 0.06 & 34.38 & 0.00 & 2.27 \\
\hline \multirow[t]{2}{*}{ Total Energy per $\$$ of Shipments } & 0.09 & 38.94 & 0.00 & 2.56 \\
\hline & \multicolumn{4}{|c|}{ Employment } \\
\hline Natural Gas per $\$$ of Value Added & 0.05 & 30.13 & 0.00 & 1.79 \\
\hline Natural Gas per \$ of Shipments & 0.09 & 28.93 & 0.00 & 1.55 \\
\hline Total Energy per $\$$ of Value Added & 0.06 & 34.05 & 0.00 & 2.18 \\
\hline \multirow[t]{2}{*}{ Total Energy per $\$$ of Shipments } & 0.08 & 33.49 & 0.00 & 2.18 \\
\hline & \multicolumn{4}{|c|}{ Producer Prices } \\
\hline Natural Gas per $\$$ of Value Added & 0.01 & 3.52 & 0.56 & 0.34 \\
\hline Natural Gas per \$ of Shipments & 0.04 & 8.31 & 0.23 & 0.70 \\
\hline Total Energy per $\$$ of Value Added & -0.03 & -15.71 & 0.03 & -1.23 \\
\hline \multirow[t]{2}{*}{ Total Energy per $\$$ of Shipments } & -0.02 & -8.34 & 0.34 & -0.67 \\
\hline & \multicolumn{4}{|c|}{ Imports } \\
\hline Natural Gas per $\$$ of Value Added & 0.00 & -2.00 & 0.88 & -0.14 \\
\hline Natural Gas per \$ of Shipments & 0.02 & 6.68 & 0.66 & 0.42 \\
\hline Total Energy per $\$$ of Value Added & -0.01 & -6.21 & 0.61 & -0.53 \\
\hline \multirow[t]{2}{*}{ Total Energy per \$ of Shipments } & 0.02 & 7.07 & 0.63 & 0.53 \\
\hline & \multicolumn{4}{|c|}{ Exports } \\
\hline Natural Gas per $\$$ of Value Added & 0.04 & 24.20 & 0.14 & 1.57 \\
\hline Natural Gas per \$ of Shipments & 0.10 & 35.73 & 0.05 & 2.00 \\
\hline Total Energy per $\$$ of Value Added & 0.03 & 16.42 & 0.26 & 1.29 \\
\hline Total Energy per $\$$ of Shipments & 0.06 & 24.24 & 0.15 & 1.69 \\
\hline
\end{tabular}

* Weighted by each industry's share of total value added or total shipments 
Figure 1

\section{U.S. Natural Gas Production}

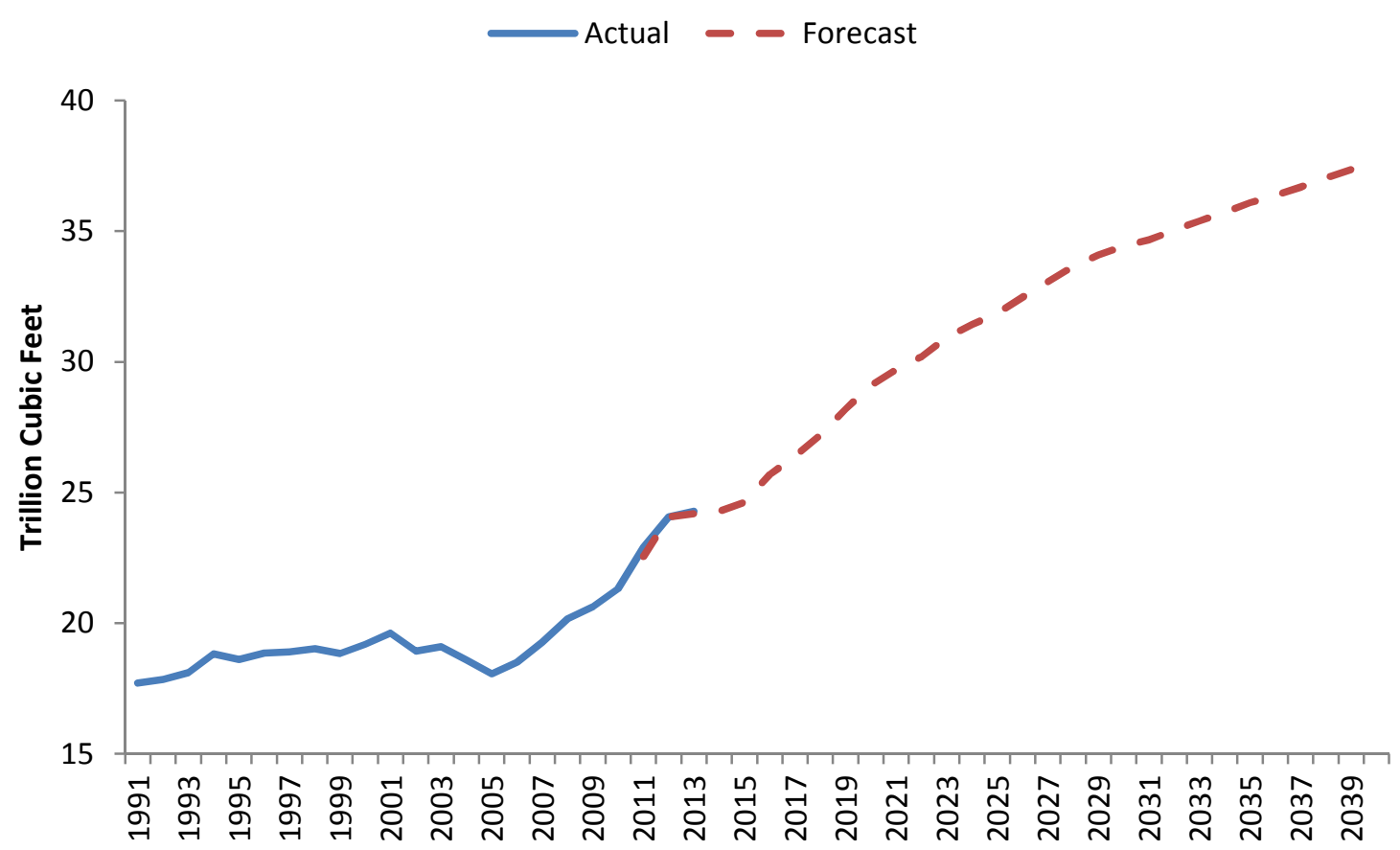

Natural Gas Prices

United States $\longrightarrow$ Europe

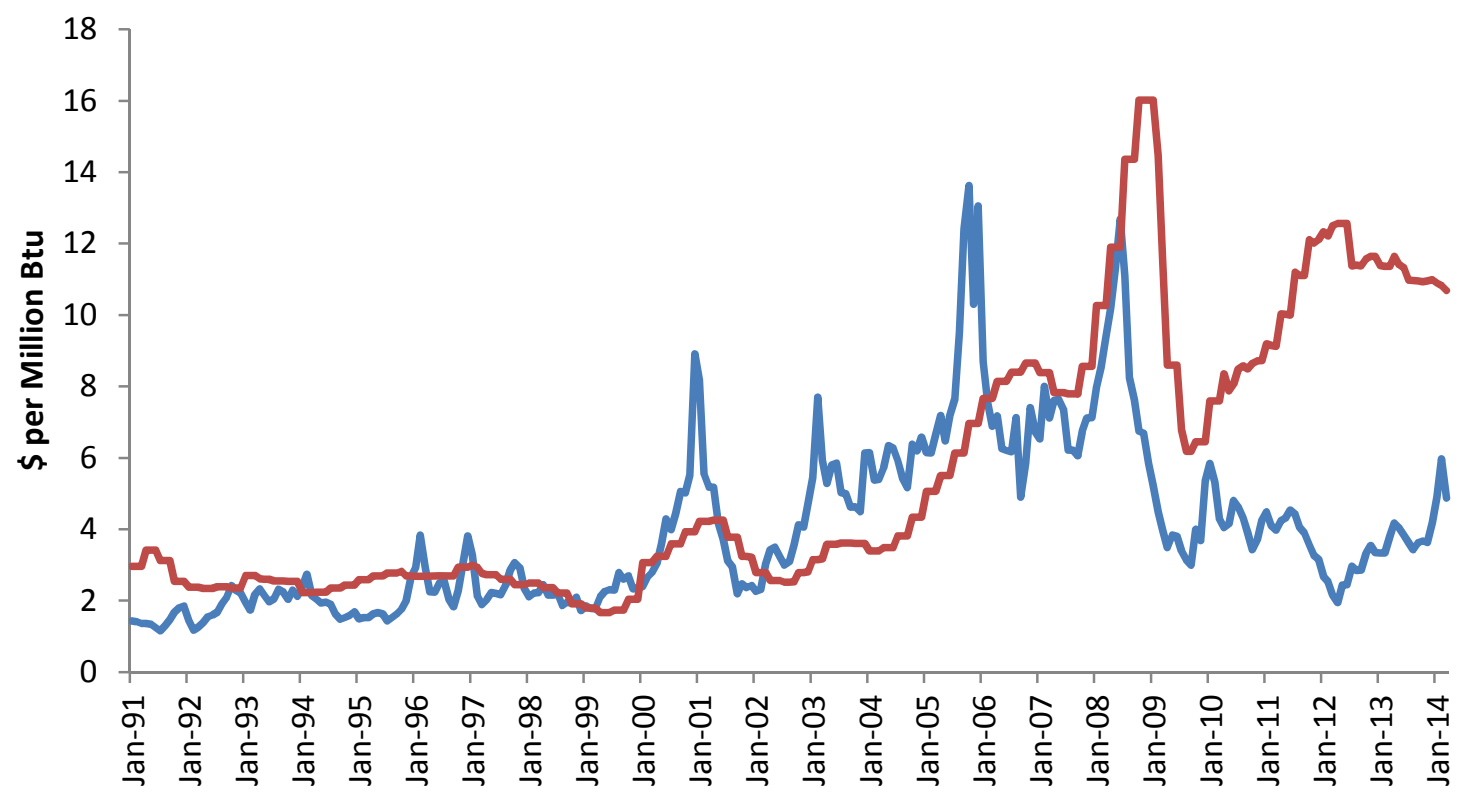

Sources: Energy Information Administration, International Monetary Fund 
Figure 2

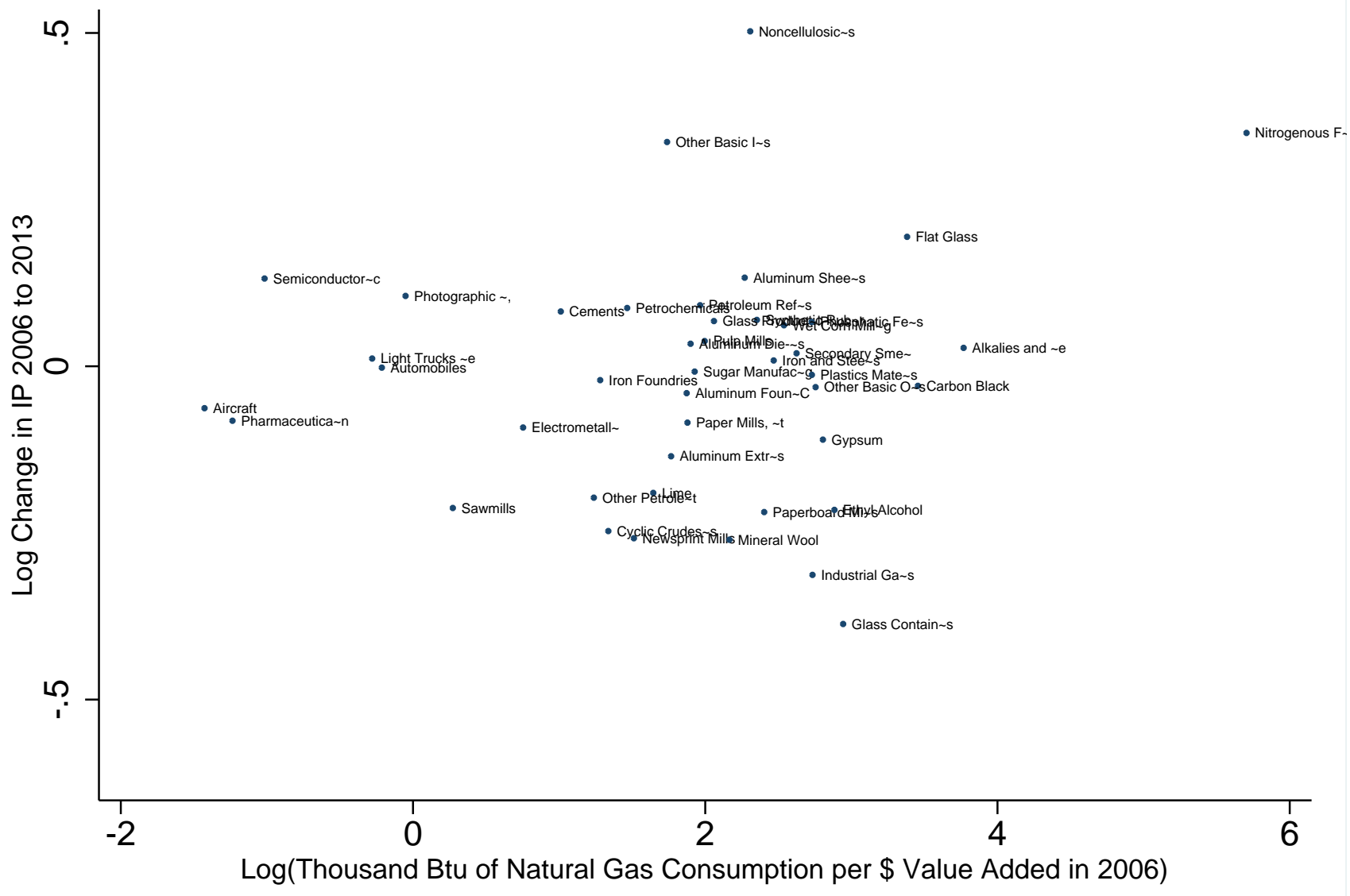

